\title{
ベトナム北部ハイハウ海岸の 発達と侵食過程に関する研究
}

\author{
工藤 祐希 1 -武若 聡 $^{2}$ \\ 1 阪急電鉄株式会社（干530-8389 大阪府大阪市北区芝田1-16-1） \\ E-mail: y.yukiideal@gmail.com \\ 2 正会員 筑波大学教授 システム情報系（テ305-8573つくば市天王台） \\ E-mail:takewaka@kz.tsukuba.ac.jp
}

\begin{abstract}
ベトナム北部ナムディン県にあるハイハウ海岸とその背後地は地域の漁業, 農業等を支える重要な沿岸域 である. 海岸の主要部（延長約 $30 \mathrm{~km}$ ）では100年来に及ぶ数百メートル規模の広域的, 長期的な侵食が進 行している。一方, この海岸の北部と南部の河口域では堆積が今も進んでおり, 紅河とその支流からは一 定の土砂供給があると推定される. 本研究では, 現在見られている侵食のメカニズムを説明することを目 的として, 過去数百年の海岸の発達過程の分析とこれが長期間に亘る侵食に転じた原因を, 文献調查, 採 取資料の年代測定, One- line model による数値的検討を通じて調べた. その結果, かつては同海岸の中央 部に紅河の流路がありここを中心にデルタが発達してきたが, これが1787年の洪水による紅河の流路変更 によりハイハウ海岸のある区間が長期的な侵食へと転じたことを明らかにした。
\end{abstract}

Key Words : Hai Hau Coast, Vietnam, coastal erosion, delta, carbon dating, One-line model

\section{1. はじめに}

ベトナム北部ナムディン県にあるハイハウ海岸（Hai Hau Coast）とその背後地は地域の漁業，農業等を支える 重要な沿岸域である（図-1）。同海岸は紅河（Red River） のデルタの一部と発達してきた．現在の海岸の主要部 （延長約 $30 \mathrm{~km}$ ) では 100 年来に及ぶ数百メートル規模 の広域的，長期的な侵食が進行している．水際部では撤 退が繰り返されており，いくつかの集落が消滅している

（写真-1）。同地域は沿岸部で多くの資産を失い，社会 的な損失が大きい ${ }^{1}$. 一一方，この海岸の北部（紅河：

Balat Estuary）と南部（Ninh Co River，Song Day River : Lach Giang Estuary）の河口域では今も堆積が進んでおり，紅 河とその支流からは一定の土砂供給があると推定される.

本研究では，現在見られている侵食のメカニズムを説 明することを目的として, 過去数百年の海岸の発達過程 の分析とこれが長期間に亘る侵食に転じた原因を，文献 調査，採取資料（貝殼）の炭素年代測定，One-line model による汀線変化の数值的検討を通じて議論する. 近年の ベトナムの経済的な発展に伴い，沿岸部の防護方法の高 度化，資産の一層の集中等が始まっているが，侵食のメ カニズムを理解できればこれらを効率的に行える.

以降では，先ず，文献調査により西暦 1000 年頃から 1900 年頃までの当該地の発達過程を説明する. 地質学

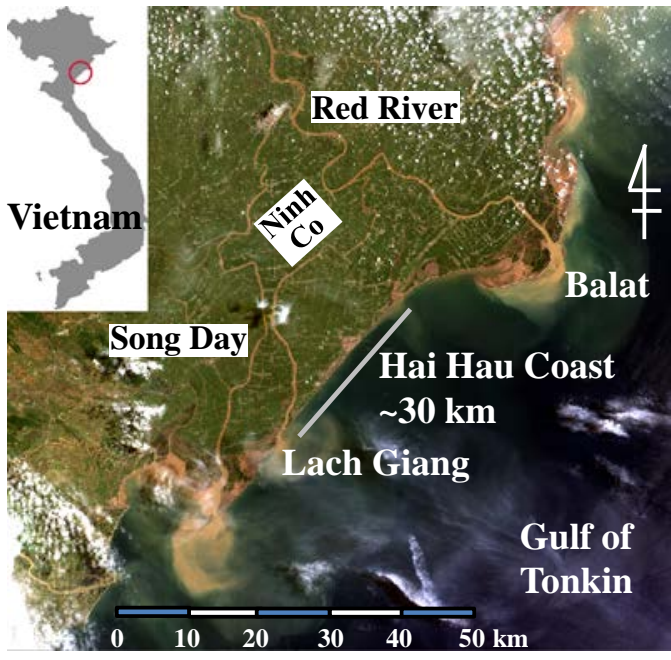

図-1 ハイハウ海岸 (ベトナム・ナムディン県)

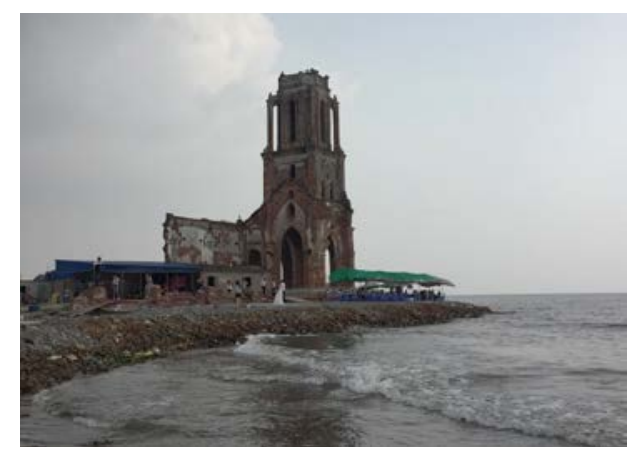

写真-1 立，1996年放棄. 撮影日：2016年10月7日 


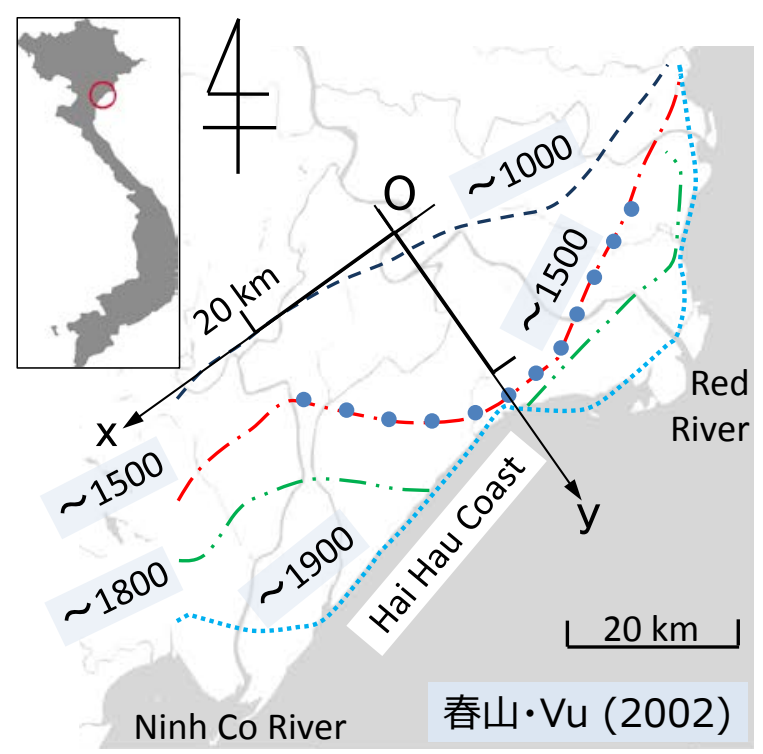

図-2 地質学的な観点より推定されたハイハウ海岸の堆 積過程 ${ }^{5} （$ 春山・Vu の図面より）。1500年頃の 汀線位置. かつての河川流路はy軸沿いにあり,こ れが，紅河（北）とNinh Co 川（南）に分岐したと 推定されている.

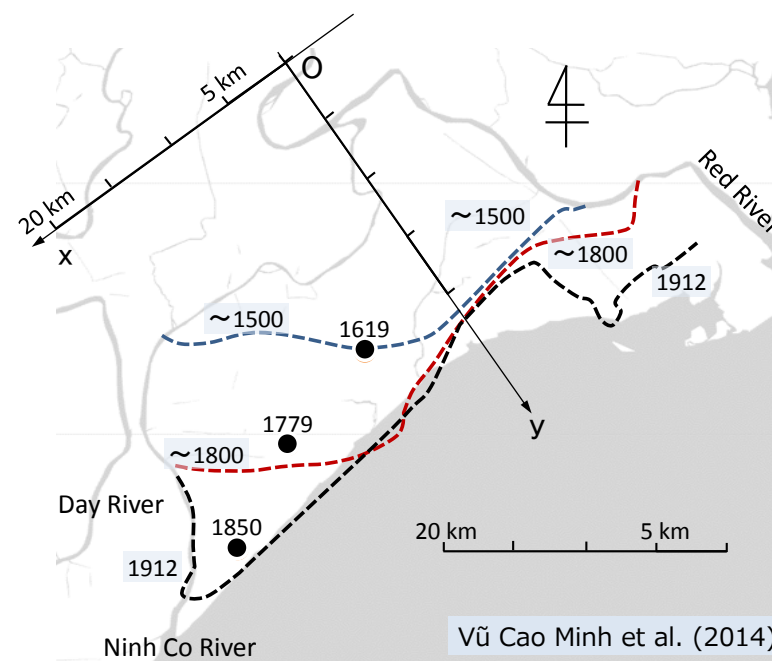

図-3人文地理学的な観点より推定されたハイハウ海岸 の堆積過程（Vuらの図面より）. れた集落の位置と時期 ${ }^{6}$.

的な調查に基づく堆積過程の推定結果，人文地理学的な 調査により説明されたデルタの堆積過程と紅河の洪水に 伴う流路変更が説明される. この際，文献調查の結果を 補足寸るために, 海岸背後地の砂層から採取された貝壳 の炭素年代測定を行い，おおよそ 1500 年以降の海岸の 堆積の速さを推定した. 以上を総合的に勘案して，1) 八 イハウ海岸の形成，2) 出水による流路変更による土砂供 給位置の変化，3)八イハウ海岸の侵食, を一連の過程と して説明する．最後に 1500 年頃から現在までの海岸線 変化を One-line model で再現し，一連の分析の裏付ける。

これまでにも八イハウ海岸の侵食に関する報告 1),2,3),4 が多くなされているが，海岸の発達過程を踏まえて議論 されることはなかった. この研究では同海岸の発達・侵

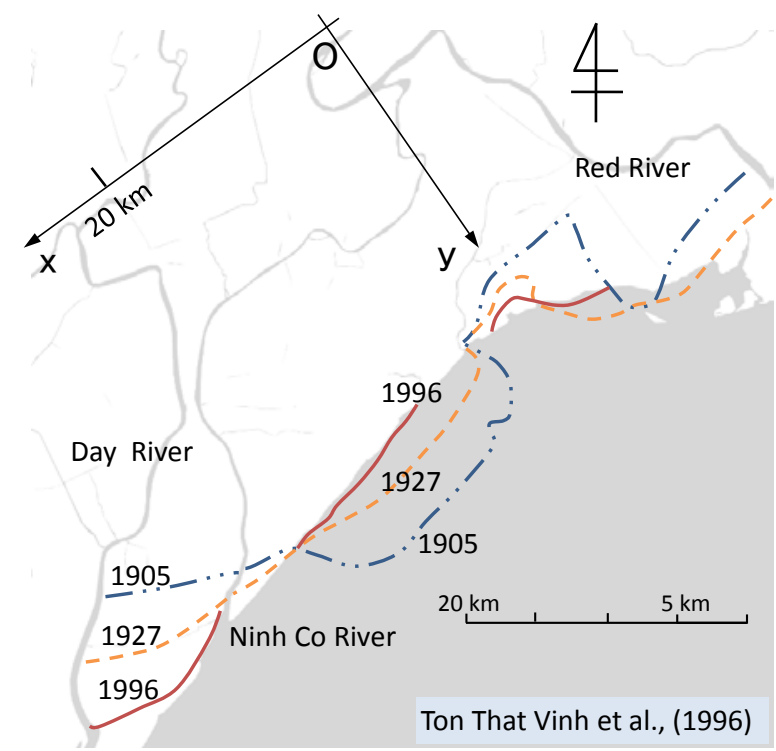

図-4 ハイハウ海岸の 1900 年代の侵食過程と南北にある

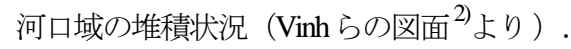

食を一連の過程として捉え, 今後の同海岸の行く末を考 える.

\section{2. 紅河デルタの発達過程}

\section{(1) 文献調査によるハイハウ海岸形成・侵食過程の整理}

現在のハイハウ海岸（図-1）は紅河デルタの一部であ り, 現在の海岸線は現在よりも発達していたかつてのデ ルタ内陸部に位置する. 紅河デルタの発達過程について は，地質学分野で多くの研究が行われており，これらを 参考に，八イハウ海岸の形成を考える.

春山と $\mathrm{Vu}^{5}$ ) はボーリング調查, 文献調査等の結果を 勘案し, 西暦 1000年以降の紅河デルタの発達過程を図-2 のように推定している.この時，紅河の主たる流路は同 図中の $\mathrm{y}$ 軸付近にあり, デルタはここを中心に発達して いたと考えられる.

当地で研究を進めている Minh らの) は, 地質学的な調 查結果に加え, 集落の形成時期, 入植過程を古文書等よ り推定し, 人文地理学的な観点も交えたデルタの発達過 程を示している（図-3）。基本的には，春山と $\mathrm{Vu}^{5}{ }^{5}$ が 示した結果と同等であり, かつては, 現八イハウ海岸の 位置に直接の土砂供給があった. 図-2, 図-3に示される 時期には, 現在のハイハウ海岸の主要部に紅河の流路が あり，ここを中心にデルタが発達しており，ハイハウ海 岸はいわゆる river dominated delta ${ }^{7}$ の主要部に位置してい た.

デルタの発達過程は, 衛星画像の判読結果からも理解 できる. シーン内に捉えられている浜堤列，田畑と道路 の構造がおおよそ東西方向に発達しており，堆積はこれ に直交するように南方に進んでいたと推定できる（図-1, 後の図-5）.

以上のデルタの発達に大きな変化が生じたのは Minh 


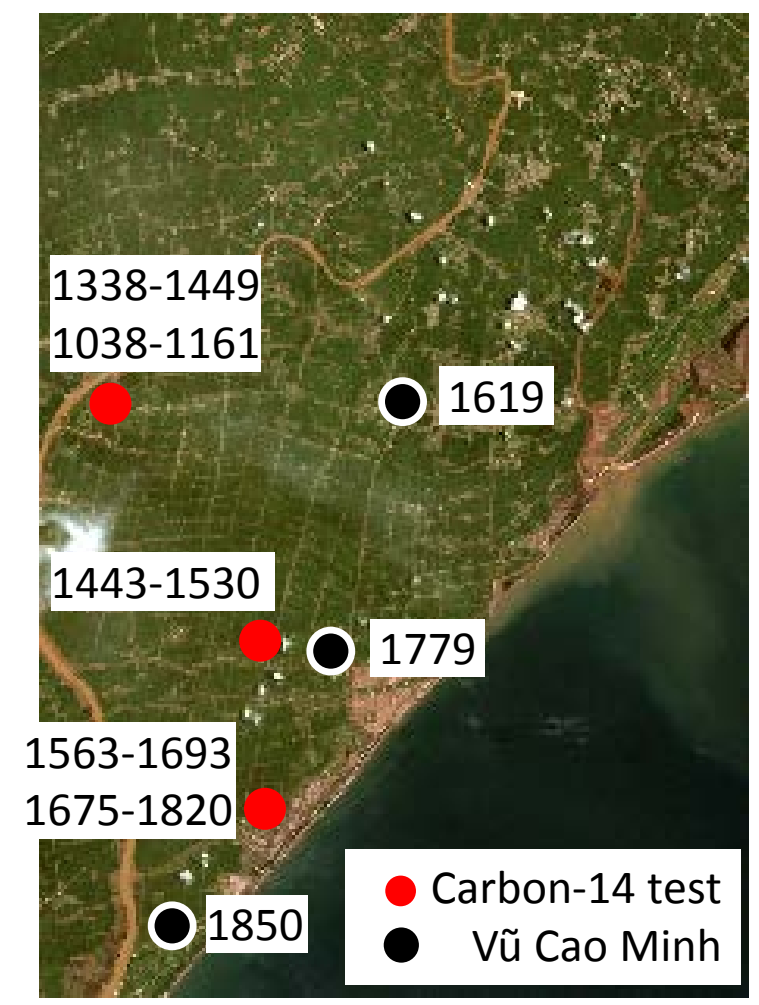

図-5 放射性炭素年代測定（○）より推定された堆積年 代と集落の位置と形成時期 ${ }^{6}$ （○）（西暦）。衛星 画像より東西方向に延びる浜堤列, 田畑・道路の 構造を判読できる.

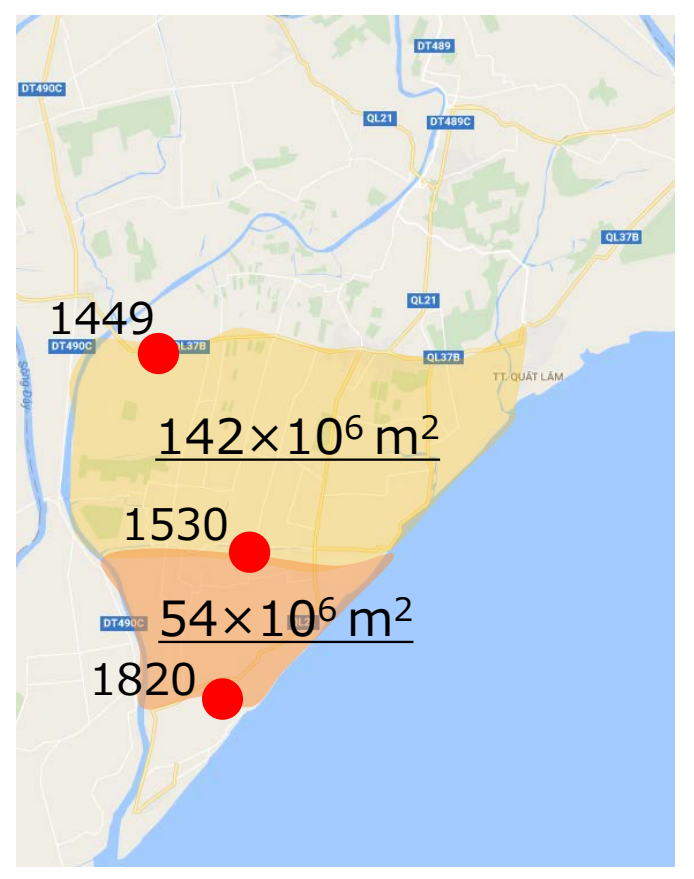

図-6 時期別の堆積面積と堆積速さ. 期間 A: 1449 年 $\rightarrow 1530$ 年, 440 万 $\mathrm{m}^{3} /$ year. 期間 B: 1530 年 $\rightarrow 1820$ 年, 46 万 $\mathrm{m}^{3} /$ year.

らが報告している 1787 年の洪水である. 大きな出水が 紅河であり, これにより, 紅河の流路が現在の位置に変 位した。この結果, 紅河と支流の流出先が現在の北部

(Balat Estuary)，南部（Lach Giang Estuary）にある河口
域に変わったことにより，ハイハウ海岸への直接の土砂 供給が絶たれた。 これにより，かつてのデルタ中心部は いわゆる wave dominated delta ${ }^{7}$ に転じ侵食が始まった。 図 -4 は 1900 年以降の侵食の進行を分析した一例である2). この報告によれば，ハイハウ海岸の主要部で汀線位置が 後退し，北部と南部の河口域で堆積が進むこととなった。 それぞれの速度は $50 \mathrm{~m} /$ 年のオーダになる.

\section{(2) 年代測定による堆積時期の推定}

既存の地質学的な研究では, 図-2 に示す 1500 年頃ま での堆積過程がボーリング調査の結果に基づき説明され ているが5, 8)，これより新しい年代については定量的な 分析結果が見当たらない，そこで，八イハウ海岸の背後 地でボーリングを行い，砂層から採取した貝款の放射性 炭素年代測定を行い, デルタの直近の時期の堆積速さを 推定した.

調査は Minh らの報告の にある集落の形成位置を参考 に図-5に示寸 3 地点とした. 現地の井戸掘り業者に掘削 を依頼し，地表面（粘土層）から直近の砂層より貝殼を 採取した. 全ての地点で, 地表の薄い粘土層下から深さ おおよそ $6 \mathrm{~m}$ までが砂層, 以深で泥層となること, 地下 水位は高かったことが確認された。

採取した貝殼の年代測定は AMS 法により行った。年 代測定の結果を図-5に示す，結果は，いずれも集落形 成時期よりも古い結果を示しており, デルタの堆積が進 行し, 土地が乾燥化してからその都度に入植があったこ とが示唆される.

\section{(3) 1500年以降の堆積速さの推定}

年代測定の結果より，この領域の流路変更前の平均的 な堆積量を求めた. 具体的には, 図-6 に示寸二つの期 間（A: 1449年 $\rightarrow 1530$ 年，B: 1530年 $\rightarrow 1820$ 年）に堆積が あった領域を定めた。 これに, 地表面の海面からの平均 的な高さ $2.5 \mathrm{~m}$ を乗じ, 各期間に堆積した土砂量（A: 35,600万 $\mathrm{m}^{3}, \mathrm{~B}: 13,400$ 万 $\left.\mathrm{m}^{3}\right)$ とした。 これらを各期間の 長さ (A: 81 年, B: 290 年) で除すことで, 年間の堆積量 の推定值とした（A: 440 万 $\mathrm{m}^{3} /$ year，B: 46 万 $\mathrm{m}^{3} / \mathrm{year}$ ) . 期 間Aの推定值を現在の紅河とその支川からの土砂供給量 の一つの推定值 (Pruszak ら ${ }^{4}$, 815 万 2,700万 $\mathrm{m}^{3} /$ year) と比較すると，その下限ではオーダが一致することより， 一定の妥当性があると考えられる. 一方, 期間 B の年 間の堆積量は期間 A に比して小さい值となっている.

これは, 流路変更が生じ, 当該域の堆積速さが減じたこ と，堆積域の一部のみを評価していることと解釈できる.

\section{3. 汀線変化}

前章でハイハウ海岸の形成過程，これが侵食に転じた 


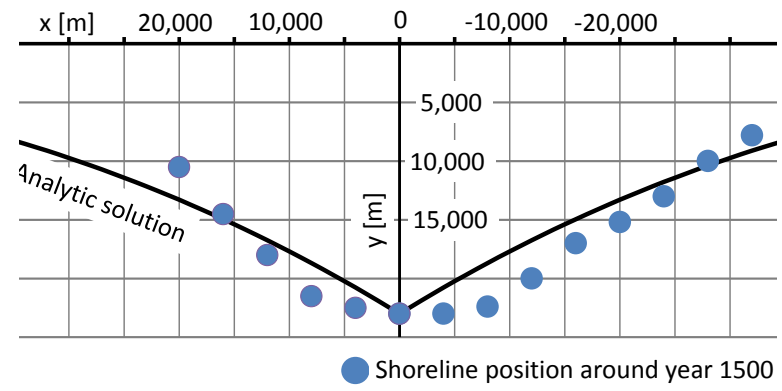

図-7 One-line model の解析解を用いた1000年から1500年ま での堆積過程の再現. (○) 春山が推定した1500年の 海岸線（図-1参照）。

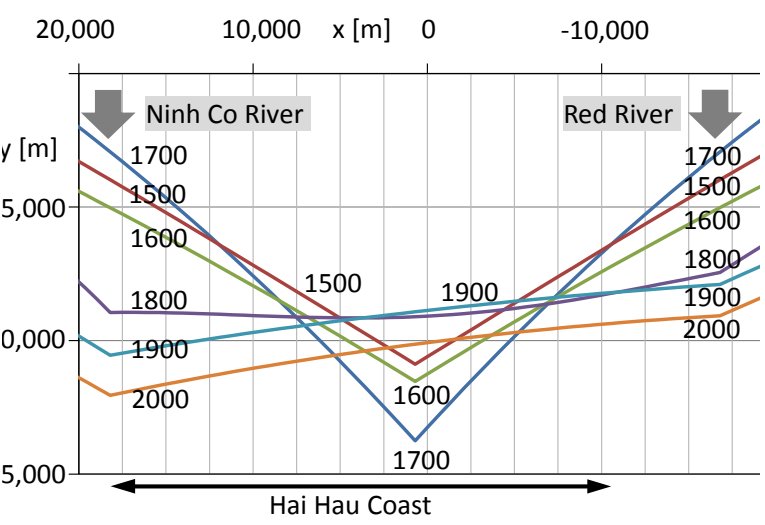

図-8 ハイハウ海岸の河川流路変更後の汀線変化. 1500 年から 2000 年までの100 年毎の汀線形状を表示. $\mathrm{y}$ $=0$ の位置にあった旧河川が 1787 年の洪水により南 北の河口域に変化した後の汀線変化をOne-line model により計算.

経過を説明した. ここでは, これらの過程により生じた 海岸線変化を洪水前後の二つの時期に分けて One-line model $^{9)}$ により計算した.

\section{(1) 1000年から1500年の汀線変化}

図-2 に示寸 1000 年から1500 年頃にかけての海岸線変 化をみると, 河川からの土砂供給によりデルタが river dominated delta として対称的に拡がって発達していたとが 理解できる. この状況を One-line model の解析解10)をつィ ッテイングして分析した. 具体的には, 波は平均的に東 南方向より，あるいは，図-2に示すy軸に沿って入射す ること，また，河口は座標系の原点にあったことを仮定 して, 河川からの土砂供給量 $\mathrm{Q}$, 沿岸漂砂の拡散係数 $\varepsilon$ を定めた。フィッテイングの結果を図-7 に示寸 $(\mathrm{Q}=$ 2,530 万 $\mathrm{m}^{3} /$ year, $\varepsilon=2.5 \times 10^{6} \mathrm{~m}^{2} /$ year $)$ ．QQ の大きさは先 に紹介した現在の紅河とその支川からの土砂供給量の一 つの推定值 (Pruszak $ら^{4}$ )， 815 万 2700万 $\mathrm{m}^{3} /$ year) に匹 敵するものとなった.

\section{(2) 1500 年以降の汀線変化}

前節で説明した One-line model の解析解により定めた
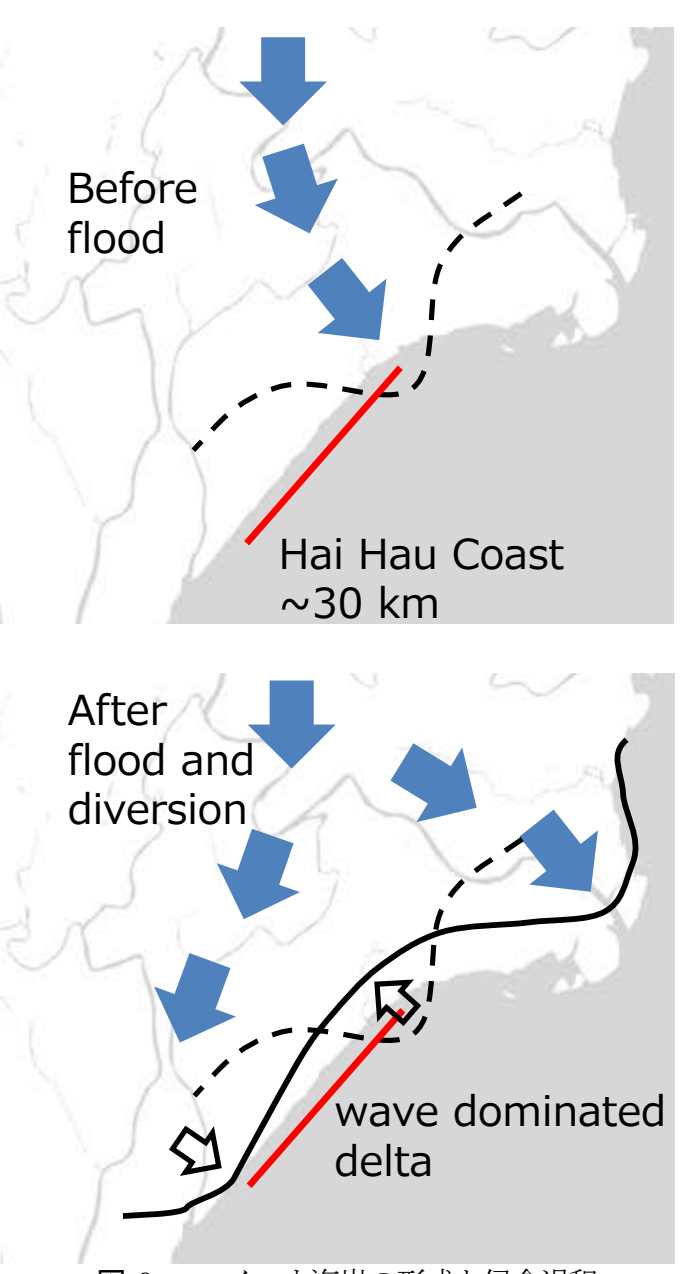

図-9ハイハウ海岸の形成と侵食過程

河川の土砂供給量 $\mathrm{Q}$ と沿岸漂砂の拡散係数 $\varepsilon$ を用い, 洪 水により生じた流路変更前後の汀線変化を次の手順によ る数值積分により求めた. 先ず, 解析解の 1500 年時点 の汀線形状を初期值として, 洪水のあった1787 年まで はデルタの中央から土砂量 $\mathrm{Q}$ を供給した．次に，1787 年以降はデルタの北部，南部にある現在の河口の位置よ り土砂を供給した。 また, 両河口からの土砂供給量は, 複数年の衛星写真の判読結果より定めた現在の河口域の 堆積量に基づき $\mathrm{Q}$ を案分して定めた（南部 $=0.67 \times \mathrm{Q}$, 北部 $=0.33 \times Q)$.

計算結果を図-8 に示寸.八イハウ海岸主要部に相当 寸る領域 $(-5,000 \mathrm{~m}<\mathrm{x}<7,500 \mathrm{~m})$ の汀線は 1900 年まで後 退し, その後, 南北にある河口から堆積域が広がる. 汀 線の後退速度は約 $20 \mathrm{~m} /$ year であり, これは侵食速さの 報告 ${ }^{22,4)}$ と概敉一致する。計算結果では，汀線後退は時 間の経過と共に和らぐが，現実には海岸侵食は継続して いる．これは，南北にある河口域の堆積土砂の固定（干 拓），河口域の発達による波浪場の変化等が，八イハウ 海岸への土砂供給を妨げていることによると考えられる.

ここで示した概念的な計算では，波浪の入射方向を一 定としていること, 沿岸漂砂の拡散係数を現在の推定值 としていないこと等，改善すべき点は多々残されている. 
しかしながら，ハイハウ海岸の主要部の漂砂環境が, river dominated delta から wave dominated delta に遷移したこ とにより生じた変化の定性的な説明はされている.

\section{4. 結言}

ハイハウ海岸の発達過程，後退に転じた要因を様々な 観点から検討した. 図-9 に本研究で考えた当海岸の変 遷を概念的に示す．継続的な海岸侵食の主因は，いわゆ る river dominated delta が河川の流路変更により wave dominated deltaに転じたことである.

現在, ベトナムの経済的な発展に伴い，当地ではこれ までより堅牢な海岸構造物による海岸防護が行われてお り，海岸線位置を堅持することとしている．その効率的 な実施にはデルタの大局的な振舞を理解した計画が必要 である，その際の留意点を以下に述べておく.

現在，ハイハウ海岸の南端部の Lach Giang Estuary では 大規模な導流堤，港湾施設の建設が行われている. 北部 の Balat Estuary では紅河からの排出土砂が固定されてい る様子が衛星画像の追跡により確認されている. これら は，八イハウ海岸への土砂供給を減少させるので, 継続 的なモニタリングが必要である. 当地の海岸は侵食が継 続しているにも関わらず，緩勾配な海底が維持されてい る（衛星画像の波峰パターンからの判読結果）。これは, 水際位置が継続的に後退していたことによると考えられ る. 今後, 水際位置を固定化すると, 汀線付近の海底が 急勾配となり，海岸構造物の安定的な維持が難しくなる 可能性がある. 八イハウ海岸の背後地では多数の深井戸 が無秩序に設けられており, 地盤沈下が懸念される.

謝辞：フィールド調査を行う際にベトナム国家大学ハ ノイ校の Tran Thi Luu 博士, Nguyen Thuy Duong 博士, Do MinhDuc准教授に多大な支援を頂いた. また，海岸背後 地の発達過程について Vietnam Academy of Water Resources のVũ Cao Minh 博士より解説と文献の紹介を頂いた. こ の研究の一部は科学研究費の支援の下に行われた.ここ
に記して謝意を申し上げます。

\section{参考文献}

1) Mai Thi Thu Thuy, 長塚信二, 西畑剛, 武若聡, 三村 信男, 安原一哉, Do Minh Duc: ベトナム北部ハイハ ウ海岸の大規模侵食の経過とその分析, 土木学会論 文集 B2 (海岸工学), Vol. 68, pp.1441-1445， 2012.

2) Ton That Vinh, G. Kant, Nguyen Ngoc Huan and Z. Pruszak: Sea dike erosion and coastal reterat at Nam Ha, Vietnam, Proceedings of $25^{\text {th }}$ International Conference on Coastal Engineering, Chapter 218, ASCE, 1996.

3) Haglund Martin, Par Svensson, Coastal erosion at Hai Hau beach in the Red River, Vietnam, Master Thesis submitted to Lund University, 2002.

4) Pruszak Zbignew, Marek Szmytkiewicz, Ngyuen Manh Hung and Pham Van Ninh, Coastal process in the Red River delta area, Vietnam, Coastal Engineering Journal, Volume 44, pp. 97-126, 2002.

5) 春山成子, Vu Van Phai : 紅河デルタ南部の沿岸域変 化, 地学雑誌, Vol. 111, pp. 126-132, 2002.

6) Vũ Cao Minh, Nguyễn Khắc Nghĩa and Nguyễn Huy Thịnh: The changes of Ba Lạt and Hà Lạn estuaries in past period and thier influencies on accretion-erosion of Hải Hậu region, Nam Định Province, Journal of Water Resources Science and Technology, Vietnam Academy of Water Resources, No. 13, 2013. (In Vietnamese)

7) Coastal Wiki: Wave-dominated river deltas, http://www.coastalwiki.org/wiki/Wave-dominated_river_d eltas, confirmed on 2017 June 28.

8) Tanabe Susumu, Yoshiki Saito, Quang Lan Vub, Till J.J. Hanebuth, Quang Lan Ngo, Akihisa Kitamura: Holocene evolution of the Song Hong (Red River) delta system, northern Vietnam, Sedimentary Geology, Volume 187, pp. 29-61, 2006.

9) 土木学会 : 水理公式集例題プログラム集, 土木学会, 2001.

10) Magnus Larson, Hans Hanson, and Nicholas C. Kraus: Analytical solutions of the one-line model of shoreline change, Coastal Engineering Research Center, U.S. Army Engineer Waterways Experiment Station, Technical Report CERC-87-15, 1987.

(2017.3.15 受付)

\section{STUDY ON LONG-TREM EROSION OF HAI HAU COAST, NORTHERN VIETNAM}

\section{Yuuki KUDO and Satoshi TAKEWAKA}

Hai Hau Coast, Nam Dinh Province, northern Vietnam is an approximately $30 \mathrm{~km}$ long sandy beach, which is suffering long-term erosion in the last hundred years. The amount of erosion exceeds 1,000 $\mathrm{m}$, and several villages in the hinterland disappeared during this recession. On the other hand, at the river estuaries, north and south of the main part of Hai Hau Coast, satellite images capture formations of newly deposited areas, which are indicating that the rivers are still putting a huge amount of sand to the coast. This study tires to understand the formation process of Hai Hau Coast, and why it turned to erosive circumstance of nowadays, from literature survey, dating of sampled shells from the hinterland, and by a numerical computation of shoreline changes with 
one-line model. From literature survey, the area was so-called river dominated delta, and was continuously accumulating by the sediment input of old Red River. A large flood diverted the old Red River to the north and south, the present river estuaries, and the coast turned to so-called wave dominated delta, and the long-term erosion has started after this event. From the results of carbon dating of the shells, speed and amount of accumulation before the flood event were estimated. After the diversion, one-line model was applied to discuss the shoreline changes, which well reproduced the on-going erosion of Hai Hau Coast. The numerical result suggests that reclamation of the deposited sediments at the estuaries is one of the possible reasons of long-term erosion, which prevents feeding sand from the river to the coast. 